\title{
Water balance estimates of ten greatest lakes in China using ICESat and Landsat data
}

\author{
ZHANG GuoQing $^{1,2^{*}}$, XIE HongJie ${ }^{3}$, YAO TanDong ${ }^{1} \&$ KANG ShiChang $^{1}$ \\ ${ }^{1}$ Key Laboratory of Tibetan Environmental Changes and Land Surface Processes, Institute of Tibetan Plateau Research, \\ Chinese Academy of Sciences, Beijing 100101, China; \\ 2 Department of Geological Sciences, East China Institute of Technology, Nanchang 330013, China; \\ ${ }^{3}$ Laboratory for Remote Sensing and Geoinformatics, University of Texas at San Antonio, San Antonio, Texas 78249, USA
}

Received December 11, 2012; accepted March 4, 2013; published online May 15, 2013

\begin{abstract}
Lake level and area variations are sensitive to regional climate changes and can be used to indirectly estimate water balances of lakes. In this study, 10 of the largest lakes in China, $\sim 1000 \mathrm{~km}^{2}$ or larger, are examined to determine changes in lake level and area derived respectively from ICESat and Landsat data recorded between 2003 and 2009. The time series of lake level and area of Selin Co, Nam Co, and Qinghai Lake in the Tibetan Plateau (TP) and Xingkai Lake in northeastern China exhibit an increasing trend, with Selin Co showing the fastest rise in lake level $(0.69 \mathrm{~m} / \mathrm{a})$, area $\left(32.59 \mathrm{~km}^{2} / \mathrm{a}\right)$, and volume $\left(1.25 \mathrm{~km}^{3} / \mathrm{a}\right)$ among the 10 examined lakes. Bosten and Hulun lakes in the arid and semiarid region of northern China show a decline in both lake level and area, with Bosten Lake showing the largest decrease in lake level $(-0.43 \mathrm{~m} / \mathrm{a})$ and Hulun Lake showing the largest area shrinkage $\left(-35.56 \mathrm{~km}^{2} / \mathrm{a}\right)$. However, Dongting, Poyang, Taihu, and Hongze lakes in the mid-lower reaches of the Yangtze River basin present seasonal variability without any apparent tendencies. The lake level and area show strong correlations for Selin Co, Nam Co, Qinghai, Poyang, Hulun, and Bosten lakes $\left(R^{2}>0.80\right)$ and for Taihu, Hongze, and Xingkai lakes $(\sim 0.70)$ and weak correlation for East Dongting Lake (0.37). The lake level changes and water volume changes are in very good agreement for all lakes $\left(R^{2}>0.98\right)$. Water balances of the 10 lakes are derived on the basis of both lake level and area changes, with Selin Co, Nam Co, Qinghai, and Xingkai lakes showing positive water budgets of $9.08,4.07,2.88$, and $1.09 \mathrm{~km}^{3}$, respectively. Bosten and Hulun lakes show negative budgets of -3.01 and $-4.73 \mathrm{~km}^{3}$, respectively, and the four lakes along the Yangtze River show no obvious variations. Possible explanations for the lake level and area changes in these four lakes are also discussed. This study suggests that satellite remote sensing could serve as a fast and effective tool for estimating lake water balance.
\end{abstract}

water balance, lakes, ICESat, Tibetan Plateau

Citation: Zhang G Q, Xie H J, Yao T D, et al. Water balance estimates of ten greatest lakes in China using ICESat and Landsat data. Chin Sci Bull, 2013, 58: 3815-3829, doi: 10.1007/ s11434-013-5818-y

Lakes are not only water resources essential for life, but also sensitive indicators of climate change. Thus, they are of great importance for water assessment, climate modeling, and environmental and biodiversity studies. A global database of lakes and wetlands shows that the total lake area in China of those larger than $1.0 \mathrm{~km}^{2}$ is $\sim 8 \times 10^{4} \mathrm{~km}^{2}$ [1], which accounts for $\sim 0.8 \%$ of China's land area. The Tibetan Plateau (TP) has the largest number of lakes, with 1055 lakes of

*Corresponding author (email: guoqing.zhang2009@gmail.com) greater than $1.0 \mathrm{~km}^{2}$, accounting for $39 \%$ and $51 \%$ of the total lake number and area in China [2], respectively, and is known as the "water tower of Asia".

The physical properties of China's lakes have been strongly affected by climate changes and human activities during recent years. For example, shrinkage and vanishing of lakes in North China such as those in Xinjiang and Inner Mongolia occurred because of warming [3] and increased agriculture irrigation [4]. The decrease in lake area in South China is attributed to reclamation, lakeshore expansion, and 
enclosure associated with rapid economic growth [5]. A recent study of 74 lakes (56 saltwater lakes) in the TP indicated that the levels of $62(84 \%)$ freshwater and $50(89 \%)$ saltwater lakes increased from 2003 to 2009 [6], which is likely due to accelerated glacier melting and increased net precipitation over the TP [6-9]. This result is also consistent with the emergence of numerous new lakes and the increase in the areas of lakes in the region [5,10,11]. The interrelationship between the Yangtze River and Poyang Lake has been altered by local and regional climate and human activities, thus affecting the ecological system, wetland cover types, and economic benefits [12-14]. In particular, the operation of the Three Gorges Dam since 2003 shows a certain degree of influence on the hydrological process of Poyang Lake basin [12].

Lake volume variations can be calculated through water inputs such as precipitation over the lake, river inflow, and groundwater recharge and outputs such as evaporation from the lake, river outflow, and groundwater seepage. However, direct measurement of these parameters at hydrological stations is usually difficult. Moreover, the remoteness and harsh conditions of high-altitude lakes present further challenges. Remote sensing has proved to be a powerful and efficient tool for monitoring these lakes [15]. Water mass balance of a lake can be indirectly estimated by combining lake level and area changes. Satellite radar/laser altimeters such as TOPEX/POSEIDON, ENVISAT, JASON-1, and ICESat/GLAS have been successfully launched to monitor lake level changes [6,16-18]. Although ICESat/GLAS al- timetry shows high precision and accuracy [6,19-22], it is a sparse sampling scheme outside the polar regions and often excludes small lakes.

The 10 largest lakes in China, namely, Bosten, Selin Co, Nam Co, Qinghai, Dongting, Poyang, Taihu, Hongze, Hulun, and Xingkai (Figure 1), each with an area of $\geqslant 1000$ $\mathrm{km}^{2}$ and together covering an area of $22711.8 \mathrm{~km}^{2}$ [2], present a representative spatial pattern distribution. These lakes are critical for China owing to the social, ecologic, and environmental benefits they provide to the country's 1.3 billion residents. However, the temporal variations in lake level and area as well as the water balance of these lakes under the conditions of rapid current climate changes and social and economic development remain unknown. In this study, we selected the 10 largest lakes in China and retrieved the lake levels by using ICESat data and areas using the Landsat Thematic Mapper (TM) and Enhanced Thematic Mapper (ETM+) data for the period 2003-2009. Finally, water volume for each lake was calculated from the lake level and area changes, and water balance was estimated.

\section{Data and methodology}

\subsection{Characteristics of the $\mathbf{1 0}$ largest lakes}

Figure 1 shows the spatial distribution of the 10 largest lakes, along with the largest river networks, in China. The physical characteristics of these lakes are summarized in Table 1.

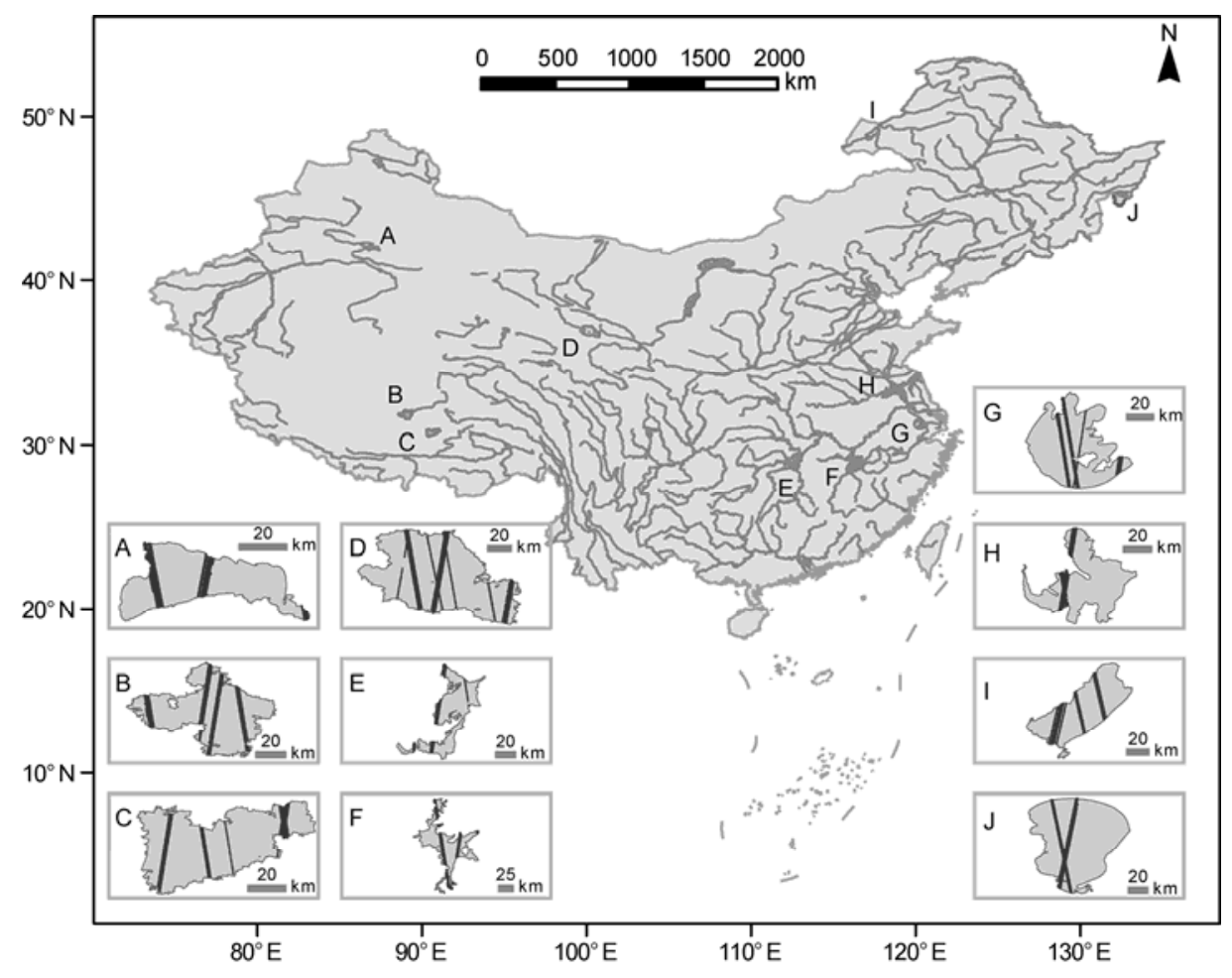

Figure 1 Locations of the 10 largest lakes in China. The insets indicate ICESat tracks passing through the lake surfaces. A represents Bosten Lake; B, Selin Co; C, Nam Co; D, Qinghai Lake; E, Dongting Lake; F, for Poyang Lake; G, Taihu Lake; H, for Hongze Lake; I, Hulun Lake; and J, Xingkai Lake. 
Table 1 Physical characteristics of the 10 largest lakes in China ${ }^{\text {a) }}$

\begin{tabular}{|c|c|c|c|c|c|c|c|c|c|c|}
\hline Characteristics & Selin Co & Nam Co & Qinghai & Xingkai & Bosten & Hulun & Poyang & Taihu & Dongting & Hongze \\
\hline Latitude & $\begin{array}{c}31^{\circ} 32.7^{\prime}- \\
32^{\circ} 7.8^{\prime}\end{array}$ & $\begin{array}{c}30^{\circ} 30.1^{\prime}- \\
30^{\circ} 55.8^{\prime}\end{array}$ & $\begin{array}{c}36^{\circ} 33.0^{\prime}- \\
37^{\circ} 14.0^{\prime}\end{array}$ & $\begin{array}{c}44^{\circ} 31.5^{\prime}- \\
45^{\circ} 20.6^{\prime}\end{array}$ & $\begin{array}{c}41^{\circ} 49.5^{\prime}- \\
42^{\circ} 6.8^{\prime}\end{array}$ & $\begin{array}{c}48^{\circ} 34.5^{\prime}- \\
49^{\circ} 19.6^{\prime}\end{array}$ & $\begin{array}{c}28^{\circ} 20.6^{\prime}- \\
29^{\circ} 45.7^{\prime}\end{array}$ & $\begin{array}{l}30^{\circ} 55.5^{\prime}- \\
31^{\circ} 33.0^{\prime}\end{array}$ & $\begin{array}{l}28^{\circ} 44.8^{\prime}- \\
29^{\circ} 32.7^{\prime}\end{array}$ & $\begin{array}{l}33^{\circ} 4.0^{\prime}- \\
33^{\circ} 38.2^{\prime}\end{array}$ \\
\hline Longitude & $\begin{array}{c}88^{\circ} 31.7^{\prime}- \\
89^{\circ} 21.7^{\prime}\end{array}$ & $\begin{array}{c}90^{\circ} 14.8^{\prime}- \\
91^{\circ} 2.8^{\prime}\end{array}$ & $\begin{array}{l}99^{\circ} 37.1^{\prime}- \\
100^{\circ} 44.9^{\prime}\end{array}$ & $\begin{array}{c}131^{\circ} 58.7^{\prime}- \\
132^{\circ} 51.1^{\prime}\end{array}$ & $\begin{array}{c}86^{\circ} 43.7^{\prime}- \\
87^{\circ} 26.1^{\prime}\end{array}$ & $\begin{array}{c}116^{\circ} 58.5^{\prime}- \\
117^{\circ} 47.4^{\prime}\end{array}$ & $\begin{array}{c}115^{\circ} 47.6^{\prime}- \\
116^{\circ} 45.4^{\prime}\end{array}$ & $\begin{array}{c}119^{\circ} 53.5^{\prime}- \\
120^{\circ} 35.0^{\prime}\end{array}$ & $\begin{array}{c}112^{\circ} 24.0^{\prime}- \\
113^{\circ} 9.6^{\prime}\end{array}$ & $\begin{array}{c}118^{\circ} 12.6^{\prime}- \\
118^{\circ} 52.3^{\prime}\end{array}$ \\
\hline Types of lake & S & $S$ & S & $\mathrm{F}$ & $\mathrm{F}$ & S & $\mathrm{F}$ & $\mathrm{F}$ & $\mathrm{F}$ & $\mathrm{F}$ \\
\hline Altitude (m) & 4539 & 4723 & 3193 & 68 & 1045 & 540 & $\sim 12$ & $\sim 1$ & $\sim 24$ & $\sim 12$ \\
\hline Max length (km) & 80 & 77 & 101 & 93 & 58 & 84 & 158 & 69 & 90 & 63 \\
\hline Max width (km) & 66 & 47 & 76 & 70 & 32 & 59 & 94 & 66 & 73 & 60 \\
\hline Max depth (m) & - & $98[25]$ & $25.5[20]$ & 10 [29] & $16[23]$ & $5[28]$ & $21.71[31]$ & $2.6[32]$ & 30.8 & 5.0 \\
\hline Lake area $\left(\mathrm{km}^{2}\right)$ & 2178 & 2018 & 4165 & 4106 & 919 & 1811 & 3289 & 2314 & 2623 & 1514 \\
\hline Water volume $\left(\mathrm{km}^{3}\right)$ & - & $84.2[25]$ & $71.6[20]$ & $17.5[29]$ & $8.8[23]$ & $13.1[30]$ & $27.6[31]$ & $4.4[33]$ & 17.8 & 2.66 \\
\hline
\end{tabular}

a) $\mathrm{S}$, for salt lake; $\mathrm{F}$, for fresh lake.

Bosten Lake (A) is located in the Xinjiang Uygur Autonomous Region, northwest China. The lake lies on the southern slope of the Tianshan Mountains with a maximum water depth of $16 \mathrm{~m}$ and water volume of $8.8 \mathrm{~km}^{3}$ [23] (Table 1). Selin Co (B), Nam Co (C), and Qinghai Lake (D) are the three largest lakes in the TP, and all are enclosed salt lakes. Selin Co and Nam Co in central TP are the highest lakes in the world with altitudes $>4000 \mathrm{~m}$. The lake basin of Selin Co has an area of $49895 \mathrm{~km}^{2}$, and the Zajia Zangbo River, the longest river in Tibet, flowing into this lake [24]. The maximum water depth of Nam Co is approximately $98 \mathrm{~m}$, and its multi-year mean water volume is $84.2 \mathrm{~km}^{3}$ [25]. The Nam Co basin of $10857 \mathrm{~km}^{2}$ is located in the northern Nyainqentanglha Range with abundant glacier coverage [24,26,27]. Qinghai Lake is the largest saltwater lake in China with an area of more than $4000 \mathrm{~km}^{2}$ (Table 2). Its drainage basin covers an area of approximately $29660 \mathrm{~km}^{2}$. The combination of precipitation and glacier/snow melting in the basin provides a major water source to Qinghai Lake [20].

Dongting (E), Poyang (F), Taihu (G), and Hongze (H)

Table 2 Lake levels derived from ICESat and area obtained from Landsat ETM+/TM data at coincident start and end dates; lake level (area, volume) changes and lake water balance between 2003 and $2009^{\text {a) }}$

\begin{tabular}{|c|c|c|c|c|c|c|c|c|}
\hline Group & Lake name & $\begin{array}{l}\text { Start elevation } \\
\text { (m) (date) }\end{array}$ & $\begin{array}{c}\text { Start area }\left(\mathrm{km}^{2}\right) \\
\text { (date) }\end{array}$ & $\begin{array}{l}\text { End elevation } \\
\text { (m) (date) }\end{array}$ & $\begin{array}{c}\text { End area }\left(\mathrm{km}^{2}\right) \\
\text { (date) }\end{array}$ & $\begin{array}{l}\text { Lake level } \\
\text { changes }(\mathrm{m}), \\
\text { rate }(\mathrm{m} / \mathrm{a})\end{array}$ & $\begin{array}{c}\text { Lake area } \\
\text { changes }\left(\mathrm{km}^{2}\right) \text {, } \\
\text { rate }\left(\mathrm{km}^{2} / \mathrm{a}\right)\end{array}$ & $\begin{array}{c}\text { Water balance } \\
\left(\mathrm{km}^{3}\right) \text {, volume } \\
\text { change rate }\left(\mathrm{km}^{3} / \mathrm{a}\right)\end{array}$ \\
\hline \multirow[t]{4}{*}{$\begin{array}{l}\text { Lake level } \\
\text { increase }\end{array}$} & Selin Co & $\begin{array}{c}4539.43 \\
(2003-02-27)\end{array}$ & $\begin{array}{c}1992.46 \\
(2003-02-02)\end{array}$ & $\begin{array}{c}4543.79 \\
(2009-04-08)\end{array}$ & $\begin{array}{c}2178.37 \\
(2009-04-23)\end{array}$ & $4.37,0.69$ & $185.91,32.59$ & $9.08,1.25$ \\
\hline & Nam Co & $\begin{array}{c}4723.39 \\
(2003-02-23)\end{array}$ & $\begin{array}{c}1987.75 \\
(2003-01-10)\end{array}$ & $\begin{array}{c}4725.42 \\
(2009-10-09)\end{array}$ & $\begin{array}{c}2018.25 \\
(2009-10-01)\end{array}$ & $2.03,0.23$ & $30.50,2.89$ & $4.07,0.33$ \\
\hline & Qinghai & $\begin{array}{c}3193.32 \\
(2003-11-16)\end{array}$ & $\begin{array}{c}4084.92 \\
(2003-11-21)\end{array}$ & $\begin{array}{c}3194.02 \\
(2009-10-02)\end{array}$ & $\begin{array}{c}4165.36 \\
(2009-09-28)\end{array}$ & $0.70,0.11$ & $80.44,11.70$ & $2.88,0.54$ \\
\hline & Xingkai & $\begin{array}{c}68.76 \\
(2003-10-19)\end{array}$ & $\begin{array}{c}4104.08 \\
(2003-10-17)\end{array}$ & $\begin{array}{c}69.03 \\
(2009-10-07)\end{array}$ & $\begin{array}{c}4106.69 \\
(2009-09-30)\end{array}$ & $0.27,0.07$ & $2.16,2.17$ & $1.09,0.32$ \\
\hline \multirow[t]{2}{*}{$\begin{array}{l}\text { Lake level } \\
\text { decrease }\end{array}$} & Bosten & $\begin{array}{c}1048.00 \\
(2003-10-22)\end{array}$ & $\begin{array}{c}995.20 \\
(2003-10-21)\end{array}$ & $\begin{array}{c}1044.89 \\
(2009-10-06)\end{array}$ & $\begin{array}{c}919.85 \\
(2009-08-18)\end{array}$ & $-3.11,-0.43$ & $-75.35,-10.57$ & $-3.01,-0.41$ \\
\hline & Hulun & $\begin{array}{c}542.75 \\
(2003-03-17)\end{array}$ & $\begin{array}{c}2027.09 \\
(2003-04-30)\end{array}$ & $\begin{array}{c}540.34 \\
(2009-04-03)\end{array}$ & $\begin{array}{c}1811.06 \\
(2009-04-14)\end{array}$ & $-2.42,-0.41$ & $\begin{array}{c}-216.03 \\
-35.56\end{array}$ & $-4.73,-0.75$ \\
\hline \multirow[t]{4}{*}{$\begin{array}{l}\text { Lake level } \\
\text { no trend }\end{array}$} & Dongting & $\begin{array}{c}24.72 \\
(2003-10-14)\end{array}$ & $\begin{array}{c}723.74 \\
(2003-10-16)\end{array}$ & $\begin{array}{c}25.41 \\
(2008-12-01)\end{array}$ & $\begin{array}{c}272.70 \\
(2008-12-16)\end{array}$ & - & - & -0.25 \\
\hline & Poyang & $\begin{array}{c}10.41 \\
(2003-11-15)\end{array}$ & $\begin{array}{c}1517.35 \\
(2003-11-03)\end{array}$ & $\begin{array}{c}10.53 \\
(2009-04-07)\end{array}$ & $\begin{array}{c}1913.82 \\
(2009-04-09)\end{array}$ & - & - & -0.90 \\
\hline & Taihu & $\begin{array}{c}0.52 \\
(2004-11-04)\end{array}$ & $\begin{array}{c}2294.19 \\
(2004-11-23)\end{array}$ & $\begin{array}{c}0.92 \\
(2009-04-09)\end{array}$ & $\begin{array}{c}2314.14 \\
(2009-04-11)\end{array}$ & - & - & 0.13 \\
\hline & Hongze & $\begin{array}{c}12.69 \\
(2003-11-14)\end{array}$ & $\begin{array}{c}1624.17 \\
(2003-11-12)\end{array}$ & $\begin{array}{c}12.13 \\
(2009-03-16)\end{array}$ & $\begin{array}{c}1514.53 \\
(2009-03-17)\end{array}$ & - & - & -0.86 \\
\hline
\end{tabular}

a) All lakes are grouped into three subgroups of lake level increase, decrease, and no obvious trend. 
Lakes in the mid-lower reaches of the Yangtze River, originating from the TP, are located in the most populated region of southeastern China and are important sources of regional water and ecosystems. Hulun Lake (I) is located in a semiarid region of Inner Mongolia Autonomous Region, China, under a continental monsoon climate with an area of $2000 \mathrm{~km}^{2}$ and maximum depth of $5 \mathrm{~m}$. It is now a closed lake with a $\mathrm{pH}$ of 9.2 and salinity of $2.5 \mathrm{~g} / \mathrm{L}$, as measured in 2009 [28]. A special lake in northeastern China, Xingkai Lake (J), stretches across the border of China and Russia.

\subsection{Hydrological and meteorological data}

The Nam Co Station for Multisphere Observation and Research (briefly, Nam Co Station), established in 2005 by the Institute of Tibetan Plateau Research, Chinese Academy of Sciences, provides hydrological and meteorological data. The station is located in the southeast region of lake at $30^{\circ} 47^{\prime} 18.24^{\prime \prime} \mathrm{N} / 90^{\circ} 58^{\prime} 32.46^{\prime \prime} \mathrm{E}$ [6]. The monthly temperature, precipitation, and pan evaporation $\left(E_{\mathrm{pan}}\right)$ data between 2003 and 2009 for the Hulun Lake basin were obtained from the China Meteorological Data Sharing Service System at http://cdc.cma.gov.cn/. Pan evaporation describes evaporation measured by open circular pans with a diameter of $20 \mathrm{~cm}$, which is more representative of surface evaporation. The 84 meteorological stations from the Meteorological Bureau of Jiangxi Province recorded monthly temperature, precipitation, and $E_{\mathrm{pan}}$ of the Poyang Lake basin during 2003-2009. In addition, the daily water level measured at Duchang Hydrological Station at Poyang Lake was collected.

\subsection{ICESat data}

The ICEsat mission, with the Geoscience Laser Altimeter System (GLAS) instrument, was launched in January 2003. The primary purpose of ICESat was to detect elevation changes of ice sheets in Greenland and the Antarctic, in addition to other scientific objectives such as global measurements of cloud and aerosol heights, land topography, and vegetation canopy heights $[34,35]$. The precision of ICESat measurement is $\sim 2 \mathrm{~cm}$ with footprints $70 \mathrm{~m}$ in diameter along 172-m interval tracks for monitoring polar ice sheets and sea ice $[35,36]$. Moreover, ICESat/GLA14 shows high accuracy for measuring inland lake levels and their changes [6,20,37]. ICESat/GlAS Release-31, covering the 10 lakes between 2003 and 2009, were acquired from the National Snow and Ice Data Center (NSIDC). The elevation and related information were extracted through the Interactive Data Language (IDL) code provided by NSIDC. The ICESat data is referenced to TOPEX/Poseidon (T/P) ellipsoid and the Earth Gravitational Model 2008 (EGM2008) Geoid in Release 531. The ICESat elevation was converted to the orthometric height with the EGM2008 Geoid provided with the original ICESat and WGS84 ellipsoid with an offset of $0.7 \mathrm{~m}$ relative to the T/P ellipsoid [20]. Studies have shown that the accuracy of ICESat may be better than $10 \mathrm{~cm}$ in monitoring lake level changes [6,20,38].

For thousands of lakes, the ICESat footprints crossing the lake surface are generally selected by the boundary derived from MODIS data with a resolution of 250/500 $\mathrm{m}[6,19]$. A pixel size of $250 \mathrm{~m}$ is still excessively coarse, as compared with the 70-m footprint of ICESat data. In this study, the lake boundaries derived from Landsat images $(30 \mathrm{~m}$ in pixel size) are used to extract ICESat footprints. Therefore, a more accurate boundary is provided to remove the outliers from the water-land transition. In particular, this action is necessary for seasonal lakes with variable lake extents. A further step for removing outliers was also conducted in data processing with ICESat parameters such as waveform saturation, and instrument gain, and final standard deviation of footprints [20].

\subsection{Landsat data and lake boundary derivation}

The Landsat TM/ETM+ archives were downloaded through the United States Geological Survey (USGS) at http://glovis. usgs.gov/. A total of 130 Landsat scenes during 2003-2009 for the 10 lakes was used in this study. The Landsat ETM+ has shown a data gap of a $22 \%$ data loss per scene due to scan line corrector failure (SLC) since May 31, 2003. The Landsat ETM+gaps are filled with a local linear histogrammatching method developed by the USGS [39]. For some lakes such as Nam Co and Selin Co, a clear lake boundary can be identified from images and delineated with visual interpretation. The lake area of Nam Co on April 16, 2009, was determined in this study to be $2014.02 \mathrm{~km}^{2}$, which is very close to $2014.66 \mathrm{~km}^{2}$ on the same date, as reported by Zhang et al. [25].

In other lakes, such as Poyang and Dongting, the water inundation extent shows large variability owing to rainfall and water exchange with the Yangtze River; therefore, a Modified Normalized Difference Water Index (MNDWI) (eq. (1)) was used to map these water bodies [40,41]. The mean of MNDWI for water is much higher than that for other land cover types such as bare land, residential areas, vegetation, and clouds. Density slicing with a mean threshold sampled from the lake surface was further performed to derive water body information $[42,43]$. The range of MNDWI threshold for the lakes in the Yangtze River basin is $0.32-0.45$ :

$$
\operatorname{MNDWI}=\left[\rho_{0.56}-\rho_{1.65}\right] /\left[\rho_{0.56}+\rho_{1.65}\right],
$$

where $\rho_{0.56}$ and $\rho_{1.65}$ are bands 2 (green band) and 5 (middle infrared band) for Land TM/ETM+, respectively.

\subsection{Water-balance derivation}

A method for computing the water volume of lakes was proposed by Taube [44] as eq. (2). We used this formula to examine the water volume changes in lake area and differ- 
ences in lake level:

$$
\Delta V=\frac{1}{3}\left(H_{2}-H_{1}\right) \times\left(A_{1}+A_{2}+\sqrt{A_{1} \times A_{2}}\right),
$$

where $\Delta V$ denotes the lake volume change from lake level $H_{1}$ with an area of $A_{1}$ to $H_{2}$ with $A_{2}$. The water volume change is achieved with two consecutive elevation and area values. The water balance can be estimated with total of all step values between 2003 and 2009.

\section{Results}

\subsection{Lake level and area changes}

Figure 2 shows the lake level derived from ICESat, area from Landsat TM/ETM+, and water volume changes during 2003-2009 for the 10 lakes. These lakes were grouped into the following three subgroups according to their lake levels and area changes, as shown in Table 2: lake level increase, decrease, and no trend. Four lakes, namely, Selin Co, Nam Co, and Qinghai Lake in the TP and Xingkai Lake in northeastern China, showed lake level and area increases. Selin Co had the fastest lake level and area increase rates from 2003 to 2009 , with respective values of $0.69 \mathrm{~m} / \mathrm{a}(4.37 \mathrm{~m})$ and $32.59 \mathrm{~km}^{2} / \mathrm{a}\left(185.91 \mathrm{~km}^{2}\right)$ against $0.23 \mathrm{~m} / \mathrm{a}(2.03 \mathrm{~m})$ and $2.89 \mathrm{~km}^{2} / \mathrm{a}\left(30.50 \mathrm{~km}^{2}\right)$ for Nam Co and $0.11 \mathrm{~m} / \mathrm{a}(0.70$ $\mathrm{m})$ and $11.70 \mathrm{~km}^{2} / \mathrm{a}\left(80.44 \mathrm{~km}^{2}\right)$ for Qinghai Lake. In addition, Selin Co had an area of $2178.37 \mathrm{~km}^{2}$ in 2009 and is currently the largest lake in Tibet; Nam Co, with an area of $2018.25 \mathrm{~km}^{2}$, previously held the title [45]. Detailed lake level changes and related snow cover/glacier changes for the three lakes were previously reported [6,20,24,46]. Xingkai Lake showed a slight increase in lake level and area with respective values of $0.07 \mathrm{~m} / \mathrm{a}$ and $2.17 \mathrm{~km}^{2} / \mathrm{a}$, or amounts of $0.27 \mathrm{~m}$ and $2.16 \mathrm{~km}^{2}$ during 2003-2009.

Hulun and Bosten lakes showed both lake level and area decreases. Bosten Lake had the faster lake level drop with a rate (amount) of $-0.43 \mathrm{~m} / \mathrm{a}(-3.11 \mathrm{~m})$ against $-0.41 \mathrm{~m} / \mathrm{a}$ $(-2.42 \mathrm{~m})$ for Hulun Lake. Hulun Lake indicates a greater area shrinkage with $-35.56 \mathrm{~km}^{2} / \mathrm{a}\left(-216.03 \mathrm{~km}^{2}\right)$ against $-10.57 \mathrm{~km}^{2} / \mathrm{a}\left(-75.35 \mathrm{~km}^{2}\right)$ for Bosten Lake.

The four lakes, namely, Dongting, Poyang, Taihu, and Hongze, located in the mid-lower reaches of the Yangtze River basin, showed intraseasonal variability in lake level and area and no trend at all. The area values were obtained with available data for dates nearest those available for lake level. For Dongting Lake. including east, south, and west sections, ICESat tracks are mainly covered in the east section, and only a few are available in the south section. Therefore, only East Dongting Lake is examined for its elevation and area changes in this study. East Dongting Lake is seasonal with mean and maximum elevations and areas of $24.67 \mathrm{~m}, 27.61 \mathrm{~m}, 447.76 \mathrm{~km}^{2}$, and $792.66 \mathrm{~km}^{2}$, respectively. Poyang Lake has an inundated area of more than 3000 $\mathrm{km}^{2}$ during rainy seasons and less than $1500 \mathrm{~km}^{2}$ during dry seasons. Lake levels and area showed abrupt increases during April-June of 2005 and 2006 and abrupt decreases that remained low in 2007-2009. Taihu Lake showed the lowest altitude, between 0.4 and $1.0 \mathrm{~m}$, among the 10 lakes and an area fluctuation of approximately $2300 \mathrm{~km}^{2}$. Hongze Lake presented a mean elevation of $\sim 12.5 \mathrm{~m}$ and a mean area of $\sim 1550 \mathrm{~km}^{2}$ with some variations.

Of the 10 lakes, Selin Co showed the most rapid lake level and area increase between 2003 and 2009, while Bosten Lake showed the fastest lake level decrease, and Hulun Lake showed the greatest area shrinkage during this period.

\subsection{Lake boundary changes}

Figure 3 shows the boundary changes of the 10 lakes. An insert presents enlarged views of lake bank changes. Selin Co showed a sharp lake boundary extent between 2005 and 2006, which is consistent with lake level (1.69 m) and area $\left(99.12 \mathrm{~km}^{2}\right.$ ) increases in the two years (Figure 2). Nam Co had a greater expansion of shorelines toward west and east. Rapid bank enlargements occurred in 2004, 2005, and 2008, which correlates with lake level and area increases (Figure 2). Qinghai Lake showed greater shoreline enlargements in the eastern portion of the lake in 2005 and 2009. The lake level and area changes in the two years also presented higher peaks. The largest lake bank extent of Xingkai Lake appeared in 2008, which is consistent with lake level and area increases.

A retreating of shoreline of Hulun Lake mainly appeared in its southern region. The lake boundary showed apparent decreases in 2004, 2007, and 2009, which is consistent with the three valleys of lake level and area changes in these three years (Figure 2). Bosten Lake, with continuous decreases in lake level and area between 2003 and 2009, showed obvious bank shrinkage.

Dongting, Poyang, Taihu, and Hongze lakes have seasonal variability due to rich rainfall and water exchange with the Yangtze River; thus, lake boundary changes can occur rapidly and are usually marked by large inundations in the wet season that decline significantly in the dry season. For example, the extent of Dongting Lake was much larger in October 2004 than in November 2005, indicating a considerable decrease. Poyang Lake had a large area in June 2006, and a substantial decrease occurred during the dry period of November 2007. The shoreline changes of Taihu Lake occurred in its northeastern and southeastern regions and were accompanied by rapid industrialization and urbanization. Hongze Lake indicated clear boundary shrinkage in 2008-2009 around the lake, which is closely related to human regulations such as increased irrigation, reclamation of wetlands, and expansion of lakeside development.

\subsection{Relationships between lake level, area, and volume}

Figure 4 shows the correlation between corresponding (or 

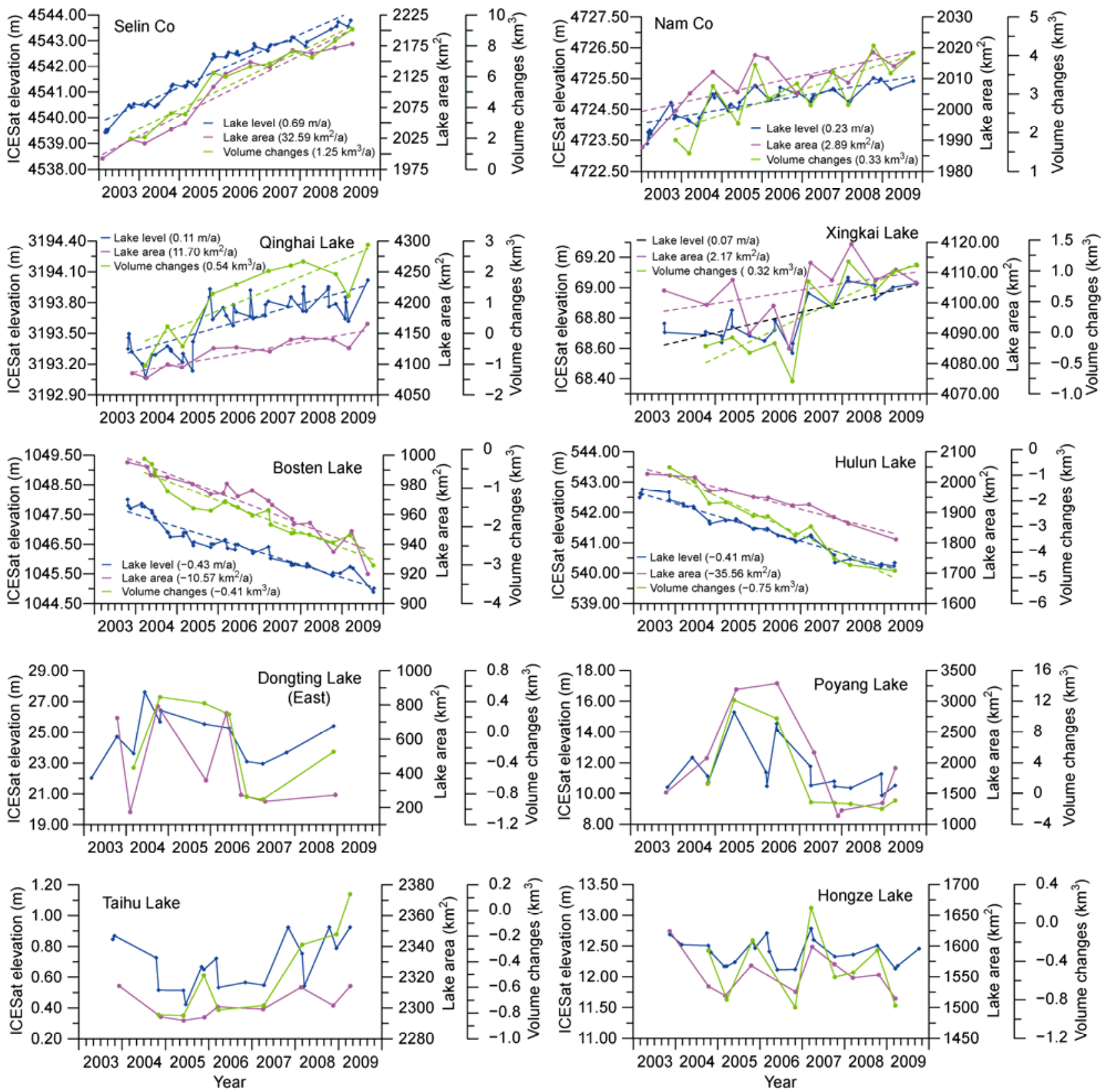

Figure 2 ICESat-derived lake level time-series (blue lines), Landsat-derived lake area time-series (red lines), and water volume changes during 20032009.

the closest available) lake area and levels for the 10 lakes. The lakes located in arid-semiarid regions including Selin Co, Nam Co, Qinghai, Hulun, and Bosten showed strong correlations $\left(R^{2}=0.83-0.96\right)$, except for Xingkai Lake with a slightly smaller value of 0.76 . The lakes in the mid-lower Yangtze River basin showed weaker correlations including 0.37 for East Dongting Lake, 0.70 for Taihu Lake, 0.71 for Hongze Lake, and 0.83 for Poyang Lake. The weaker relationship between lake level and area for these four lakes could be partly due to sparse ICESat data coverage, while frequent changes of water surface extent occur with weather changes.

A third-grade polynomial regression shows a high corre- lation $\left(R^{2}>0.98\right)$ between water level changes and water volume changes for the 10 lakes (Figure 5).

\subsection{Water balance estimation}

Table 2 shows the water volume changes of the 10 lakes and their water balances between 2003 and 2009. Results show that the lakes in the TP (Selin Co, Nam Co, and Qinghai Lake) and Xingkai Lake had a positive balance. Selin Co showed a maximum volume increase of $9.08 \mathrm{~km}^{3}$ with a rate of $1.25 \mathrm{~km}^{3} / \mathrm{a}$. Bosten and Hulun lakes showed respective water volume decreases of -3.01 and $-4.73 \mathrm{~km}^{3}$ and change rates of -0.41 and $-0.75 \mathrm{~km}^{3} / \mathrm{a}$. The lakes in the 

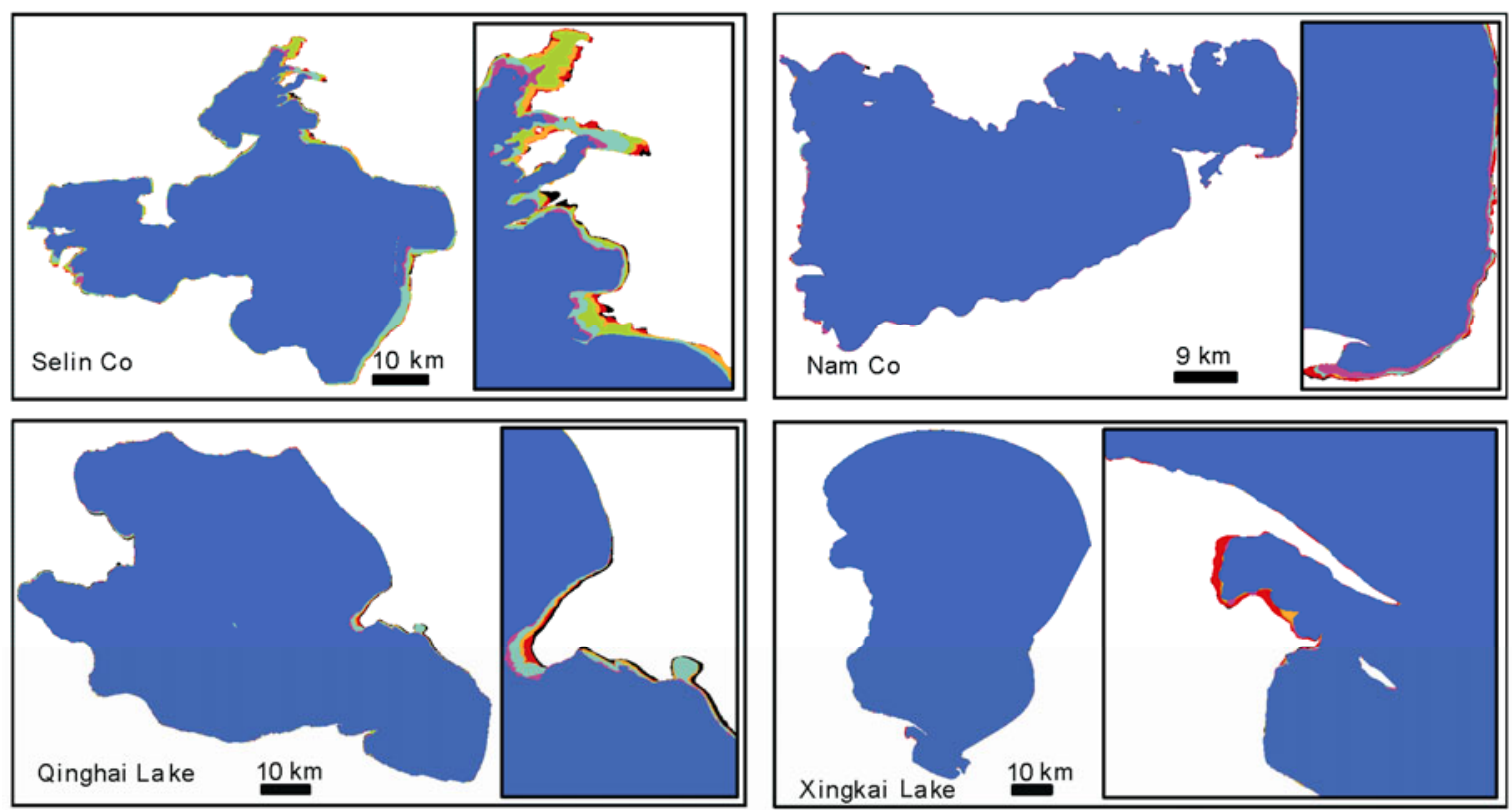

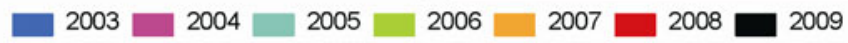
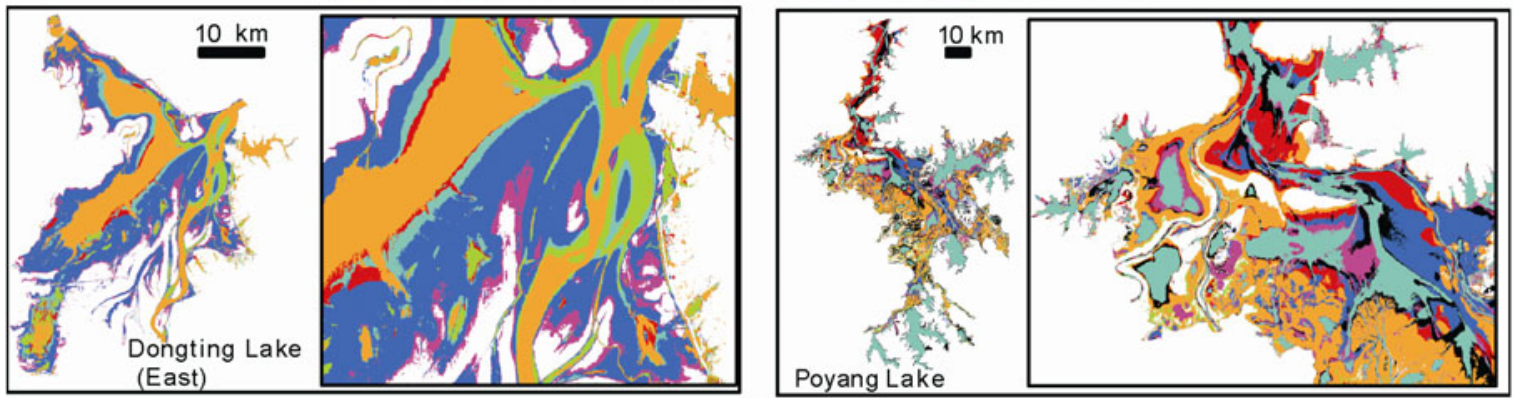

Dongting Lake(East) $\square$ 2007-04-18 $\square$ 2006-09-22 2008-12-16 $2005-11-22$ 2003-10-16 2004-10-02 Poyang Lake
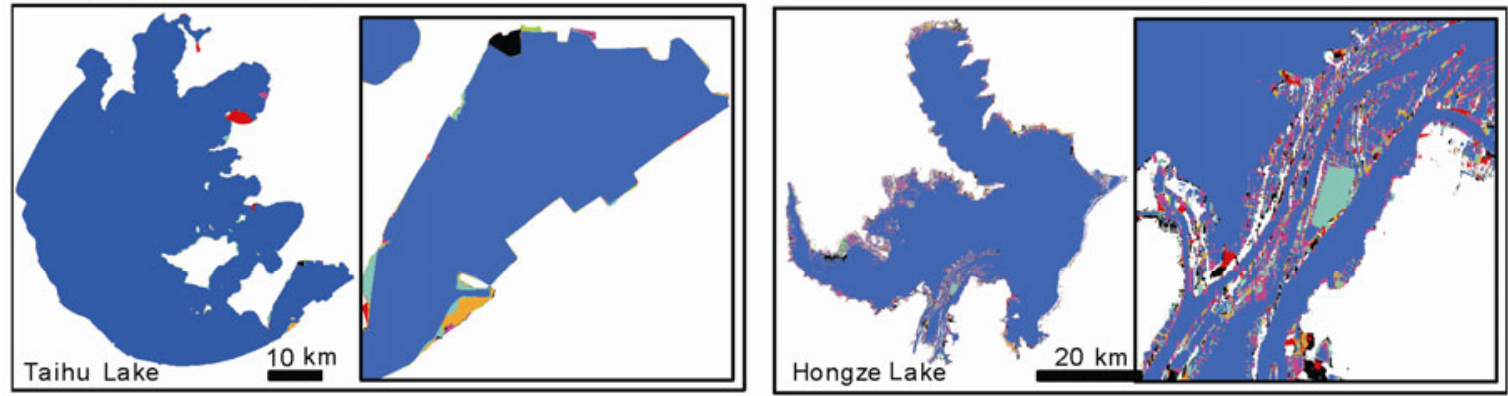

Taihu Lake $\square$ 2004-11-23 $\square$ 2005-11-26 $\square$ 2007-04-06 $\square$ 2006-03-18 2008-11-18 $\square$ 2009-04-11 $\square$ 2003-12-07 Hongze Lake $\square$ 2009-03-17 $\square$ 2008-10-24 $\square$ 2007-10-06 $\square$ 2006-11-04 $\square$ 2005-10-16 2004-10-13 $\square$ 2003-11-12
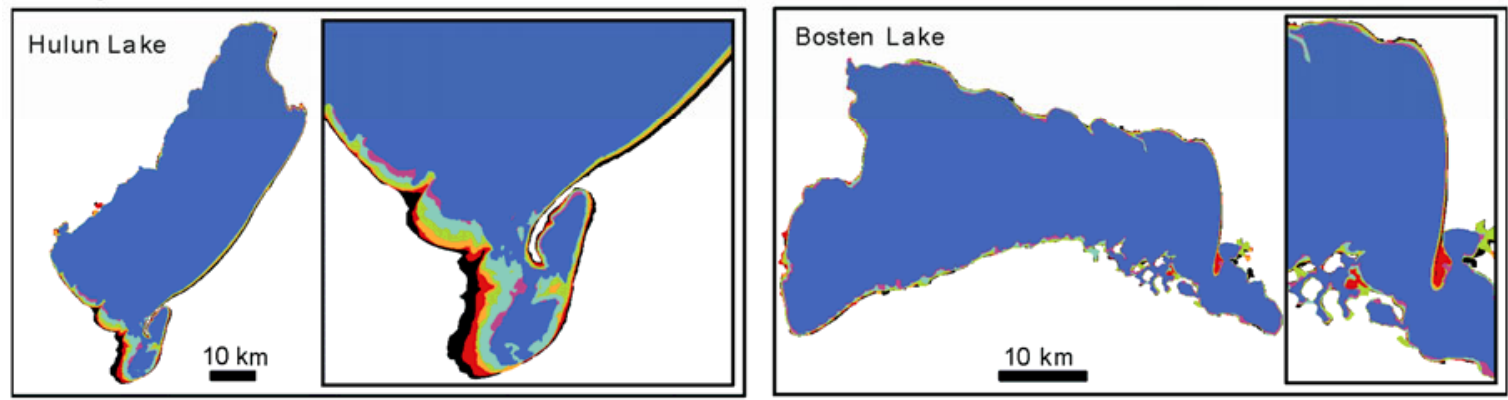

$2009 \square 2008 \quad 2007 \quad 2006 \quad 2005 \square 2004$

Figure 3 Lake boundaries delineated from Landsat imagery, with insets showing enlarged views of shoreline changes. 

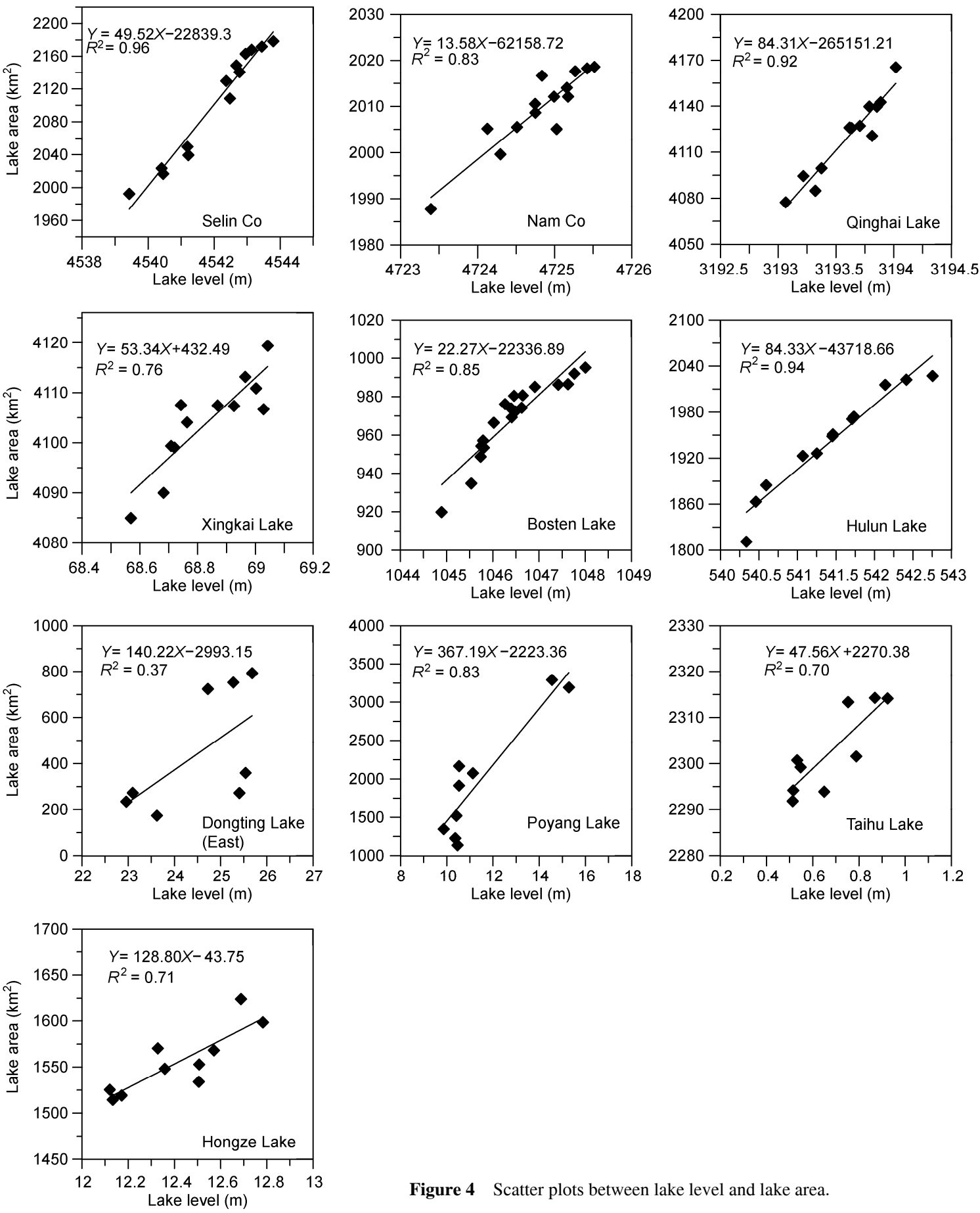

Figure 4 Scatter plots between lake level and lake area.

mid-lower reaches of the Yangtze River (Dongting, Poyang, Taihu, and Hongze) presented slight volume fluctuations of $-0.25,-0.90,0.13$, and $-0.86 \mathrm{~km}^{3}$, respectively.

\section{Discussion}

Lake level and area changes are closely related to precipitation and evaporation over lake surfaces and water recharge and discharge of the rivers within the lake basins. Three representative lakes-Nam Co, with a lake level increase in the TP, and Hulun and Poyang, with a water level decrease, and no apparent trend, respectively, in the mid-lower reaches of the Yangtze River Basin-were selected to discuss the possible causes of lake level and area changes by using available meteorological data.

Figure 6 shows the daily precipitation and $E_{\text {pan }}$ measured at Nam Co Station since 2006. The annual $E_{\text {pan }}$ in 2008- 

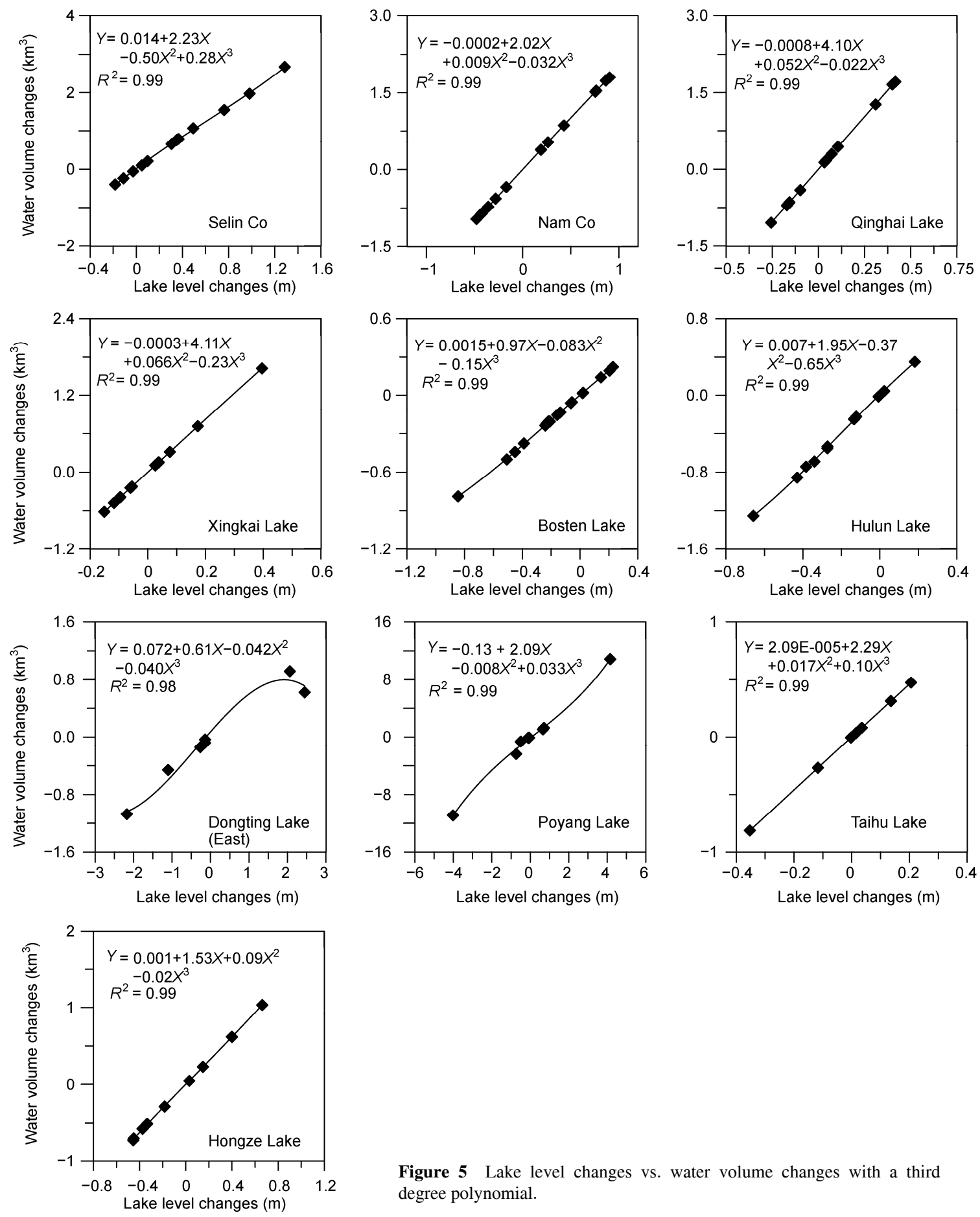

Figure 5 Lake level changes vs. water volume changes with a third degree polynomial.

2010 was $1645.85,2051.74$, and $2007.50 \mathrm{~mm}$, respectively. Rainfall in the lake basin is usually from April through October. The annual precipitation in 2006-2008 showed an increase, particularly in 2008, which is consistent with lake level, area, and volume variations recorded in the three years. The year 2009 presents a small precipitation while similar or slightly greater $E_{\mathrm{pan}}$. But the lake level (area and volume) still increased. This suggests that in addition to precipitation and evaporation, snow cover and glaciers play an important role in the water budget for the basin. As illustrated by recent studies, the rapid shrinking of glaciers in the Nyainqêntanglha Range play an important role in lake level and area changes of Nam Co [26,27,47,48]. Quantitative analyses of lake level changes and snow cover together with precipitation and $E_{\text {pan }}$ for Nam Co and Selin Co have also been reported [24,49].

Reasons for level and area changes of Hulun Lake were examined by using the four nearest meteorology stations 


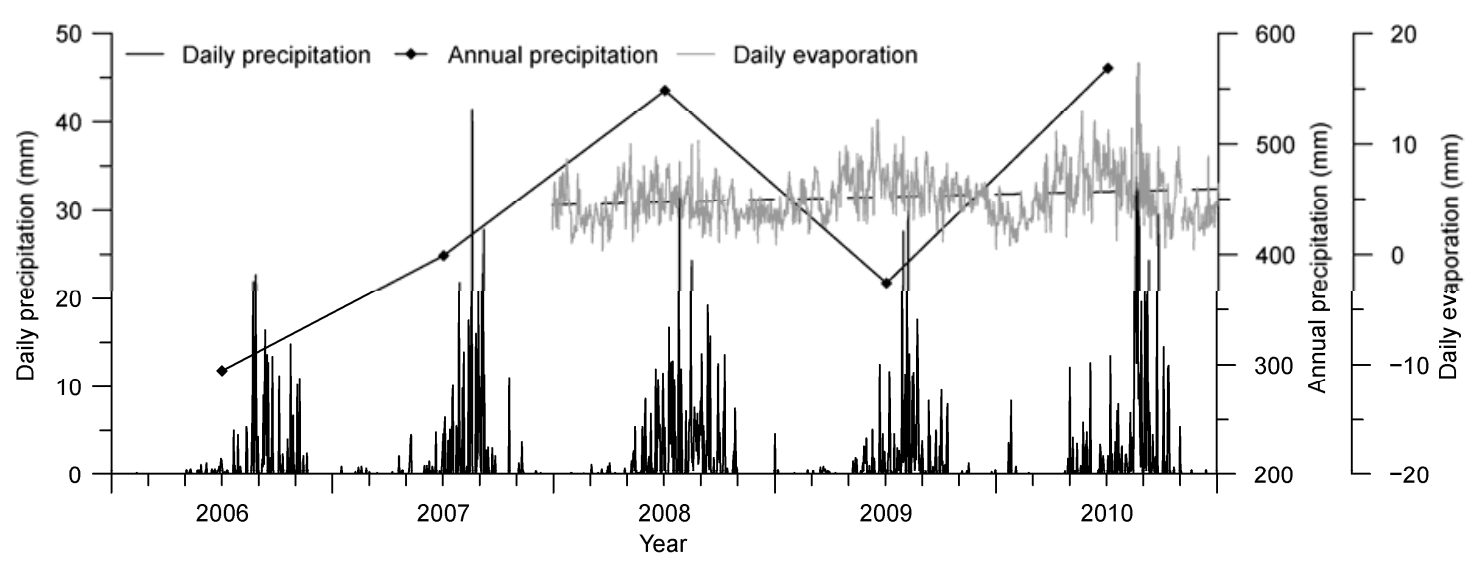

Figure 6 Daily precipitation and $E_{\mathrm{pan}}$ observed at station Nam Co during 2006-2010. The $x$-axis for each year is presented in the order of January, March, May, July, September, and November.

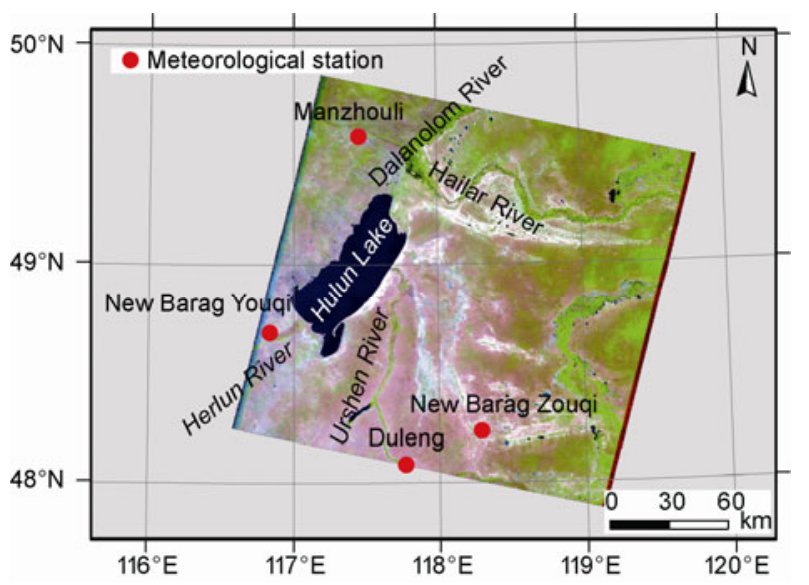

Figure 7 Location of meteorological stations near Hulun Lake including Manzhouli (MZL), New Barag Youqi (NBY), New Barag Zuoqi (NBZ), and Duleng (DL).

Including Manzhouli (MZL), New Barag Youqi (NBY), New Barag Zuoqi (NBZ), and Duleng (DL) (Figure 7). The monthly and annual temperature, precipitation, and $E_{\text {pan }}$ from 2003 to 2009 were used in this study. The monthly temperature at stations MZL, NBY, and NBZ showed seasonal variability and an overall increase in average annual temperature (Figure 8). The precipitation data from the three stations showed slight decreases in 2003-2005 followed by obvious increases in 2006-2009. Annual $E_{\mathrm{pan}}$ indicated no obvious trend with several fluctuations. The differences between average annual $E_{\mathrm{pan}}$ at station DL and precipitation from the three stations ( $E_{\mathrm{pan}}$ minus precipitation) during 2003-2007 showed increases with slight decreases in 2006, which is consistent with general lake level, area, and volume declines with slight increases in 2006-2007 (Figure 2). Although these differences show decreases in 2008 and 2009, lake level and area changes are not clear in 2009 due to limited ICESat data. Overall, the negative difference between precipitation and $E_{\text {pan }}$ play a key role in decreases of lake level, area, and volume. In addition, the degradation of seasonally frozen soil with warmer tempera- ture and river closure of two tributaries upstream of Hulun Lake could partially contribute to the decrease in lake level [50,51].

Poyang Lake, located in the northern Jiangxi Province and south of the Yangtze River, is the largest freshwater lake in China with an area of $\sim 3000 \mathrm{~km}^{2}$. The lake drainage area of $162000 \mathrm{~km}^{2}$, which occupies approximately $97 \%$ of Jangxi Province, has been an important habitat for wildlife and domestic water supply for more than 40 million populations [52]. Five major rivers including the Xiushui, Gangjiang, Fuhe, Xingjiang, and Raohe flow into Poyang Lake, and six hydrologic stations are located in its basin (Figure 9). Figure 10 shows the daily and mean annual lake levels derived from gauge measurements at Duchang station and available daily ICESat-derived water levels. Gauge measurements show clear seasonal variations with water level increases during March-August and decreases during September-February, in addition to overall decreases during 2003-2009. The ICESat water levels overlap with gaugemeasured water levels with $R^{2}=0.86$ between corresponding gauge and ICESat measurements.

Figure 11 shows monthly and average annual temperature, precipitation, and $E_{\mathrm{pan}}$ changes between 2002 and 2009 from 84 stations in the Poyang Lake basin, Jiangxi Province. The difference of annual precipitation and $E_{\text {pan }}$ (precipitation minus $E_{\mathrm{pan}}$ ) showed a decrease, which could have contributed to the overall decrease of the lake level shown in Figure 10. However, differences were present the intra-annual pattern, particularly in 2003 and 2006. The mean lake level in 2003 was the highest, whereas the difference between precipitation and $E_{\mathrm{pan}}$ was low. These results are due to the highest difference between precipitation and $E_{\text {pan }}$ of the previous year (2002). The difference between precipitation and $E_{\mathrm{pan}}$ in 2006 was high, while the mean lake level was low. Most of area in the upper reaches of the Yangtze River experienced extreme drought in the summer of 2006, and the runoff of the Yangtze River reached the lowest level among the last 50 years [53]. The extreme drought event has resulted in early onset and long duration of the dry season 


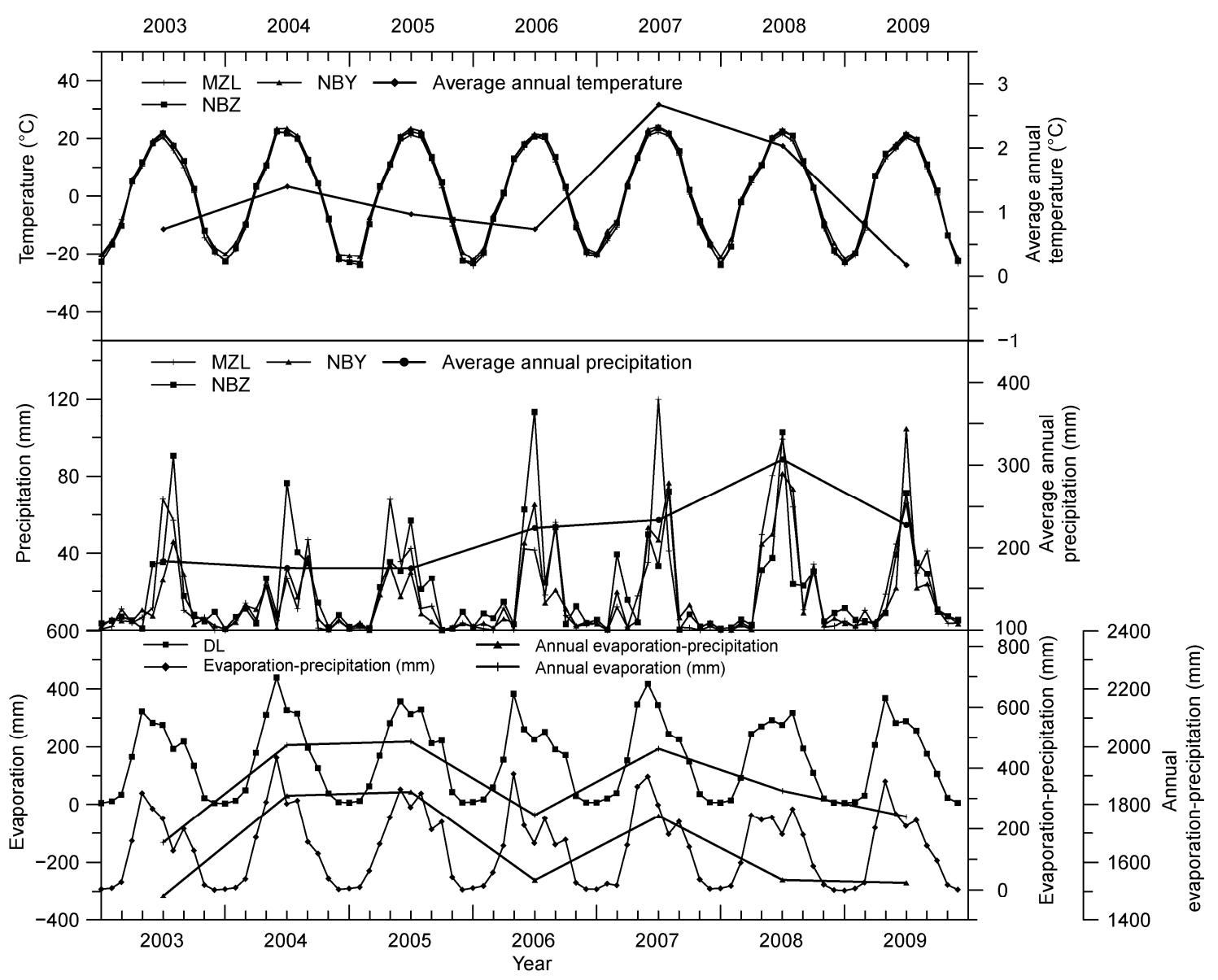

Figure 8 Monthly temperature and precipitation observed at meteorological stations Manzhouli (MZL), New Barag Youqi (NBY), New Barag Zuoqi (NBZ) and annual average from three stations and monthly $E_{\mathrm{pan}}$ at station Duleng (DL) during 2003-2009. The differences between the average annual precipitation of stations MZL, NBY and NBZ and $E_{\mathrm{pan}}$ from station DL ( $E_{\mathrm{pan}}$ minus precipitation) during the same period are also presented.

for Poyang Lake (Figure 10). In addition, the lower runoff of the Yangtze River and impoundment of the Three Gorges Dam increased replenishment from lake and tributaries to the Yangtze River in 2006 [12,53]. These factors could have resulted in the decrease of lake level, although the precipitation in the Poyang Lake basin showed no obvious change.

The lakes in the mid-lower reaches of the Yangtze River basin could have experienced more influence from human activities than from climate effect. A stronger increase in annual precipitation and weaker warming rate were reported in the humid South China than those in the northeastern region $[54,55]$. However, the number of vanished lakes in the mid-lower reaches of the Yangtze River basin account for approximately $40 \%$ of total loss of lakes in China. This result is mainly attributed to human activities such as reclamation, expansion of lakeside development, and enclosures [5].

\section{Conclusions}

In this study, we derived lake levels and area from ICESat altimetry data and Landsat data, respectively. The water balances of the 10 largest lakes in China during 2003-2009 were estimated, and the lakes were grouped into three subgroups according to the lake level and area trends.

Selin Co, Nam Co, and Qinghai Lakes in the TP showed greater lake level and area increases. Selin Co showed the most rapid lake level $(0.69 \mathrm{~m} / \mathrm{a})$ and area $(32.59 \mathrm{~km} / \mathrm{a})$ increase with a water balance of $9.08 \mathrm{~km}^{3}$ and rate of 1.25 $\mathrm{km}^{3} / \mathrm{a}$. The positive water balance of Nam Co and Qinghai Lake was 4.07 and $2.88 \mathrm{~km}^{3}$, respectively. In addition, Xingkai Lake, which crosses the border of China and Russia, showed slight lake level $(0.07 \mathrm{~m} / \mathrm{a})$ and area $\left(2.17 \mathrm{~km}^{2} / \mathrm{a}\right)$ increases with a water balance of $1.09 \mathrm{~km}^{3}$. Bosten and Hulun Lakes in arid and semiarid China showed substantial lake level, area, and volume decreases with respective rates of $-0.43 \mathrm{~m} / \mathrm{a},-10.57 \mathrm{~km}^{2} / \mathrm{a}$, and $-0.41 \mathrm{~km}^{3} / \mathrm{a}$ and $-0.41 \mathrm{~m} / \mathrm{a}$, $-35.56 \mathrm{~km}^{2} / \mathrm{a}$, and $-0.75 \mathrm{~km}^{3} / \mathrm{a}$; water balances were -3.01 and $-4.73 \mathrm{~km}^{3}$, respectively. The area and water level changes of Dongting, Poyang, Taihu, and Hongze lakes in the mid-lower reaches of the Yangtze River basin showed seasonal variability.

Three of the 10 lakes, one in each group, were selected to 

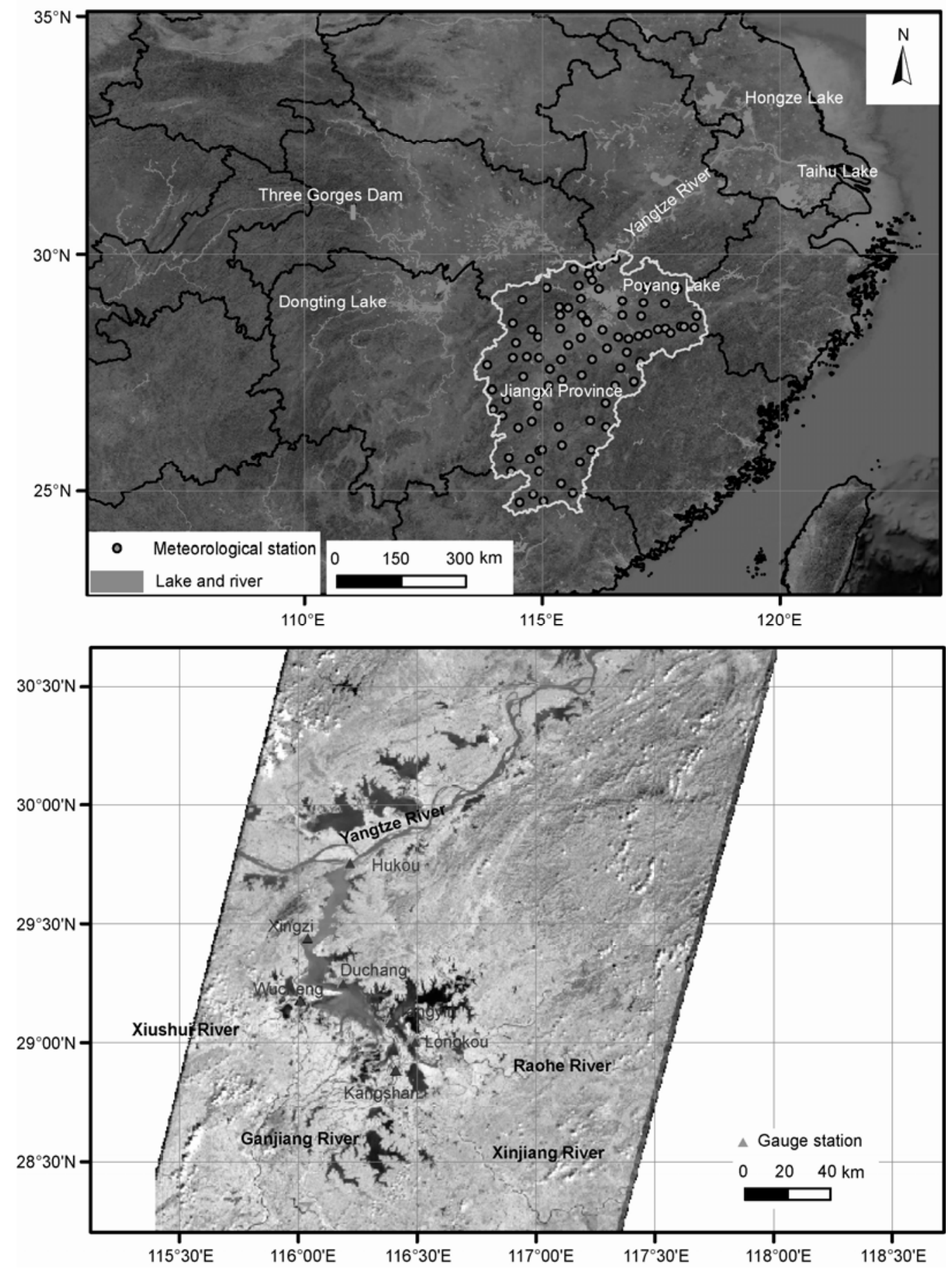

Figure 9 Dongting, Poyang, Taihu, and Hongze lakes; Three Gorges Dam along the Yangtze River; and 84 meteorological stations in Jiangxi Province (top panel). Five major tributary rivers, Xiushui, Ganjiang, Fuhe, Xinjiang, and Raohe, discharge into Poyang Lake. Six hydrological stations are annotated (bottom panel).

discuss the possible causes of lake level and area changes. The increases in lake level and area in the TP are primarily caused by increased precipitation in addition to accelerated melting of snow cover and glaciers. The greater negative balance between precipitation and evaporation triggered lake level and area decreases in the arid and semiarid region such as Bosten and Hulun lakes. The lake level and area in the mid-lower reaches of the Yangtze River basin has strong seasonal variations in wet and dry seasons. Poyang Lake is examined within the entire basin with rich meteorological data. A slight decrease in lake level was affected by regional climate changes coupled with anthropogenic activities. This study suggests that water balance of lakes can be estimated by combining satellite-derived lake area and level 

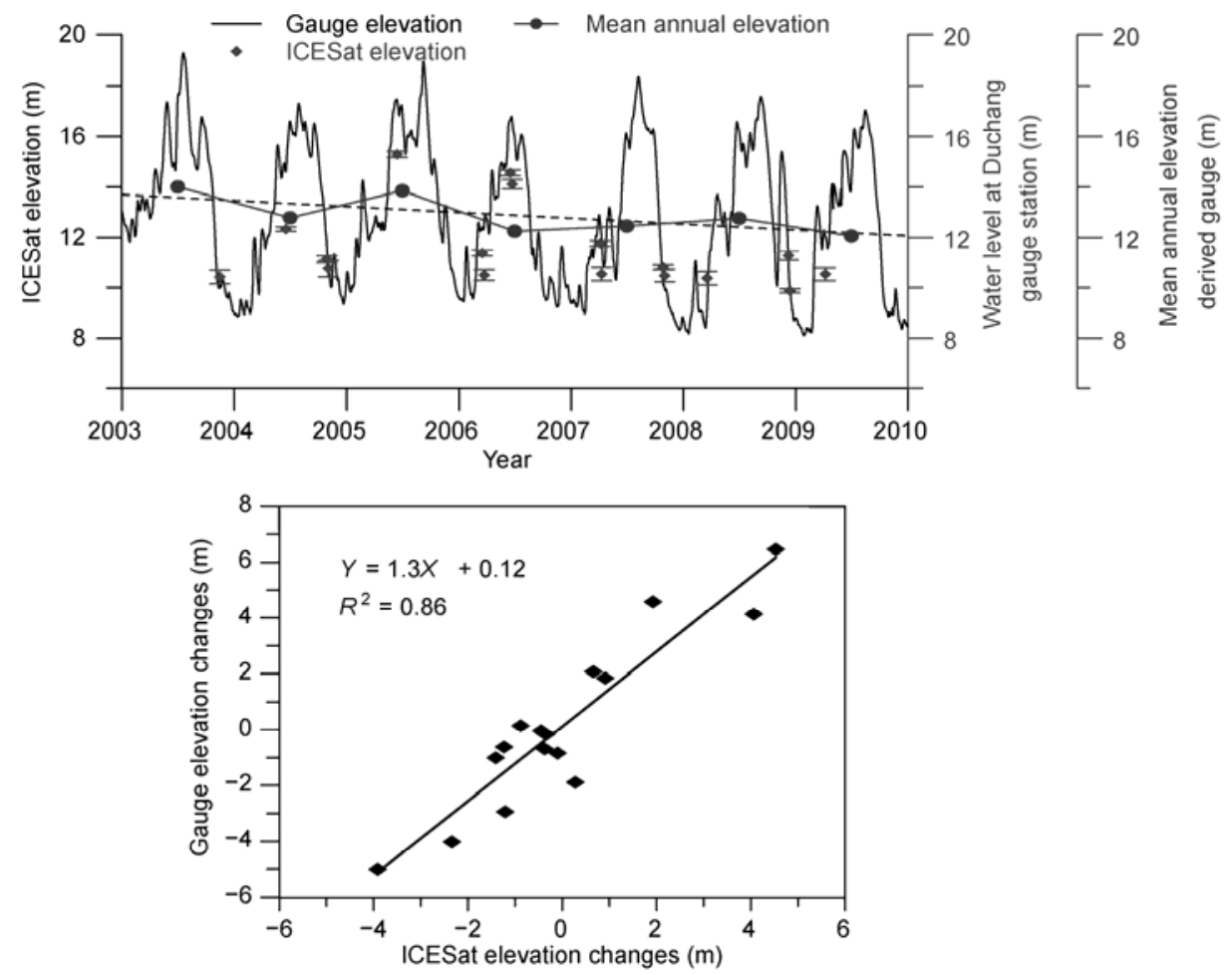

Figure 10 Lake levels derived from ICESat data with standard deviation for daily and annual water levels observed at Duchang Hydrological Station at Poyang Lake (top panel). The relationship between lake level changes derived from ICESat and gauges is also given (bottom panel).

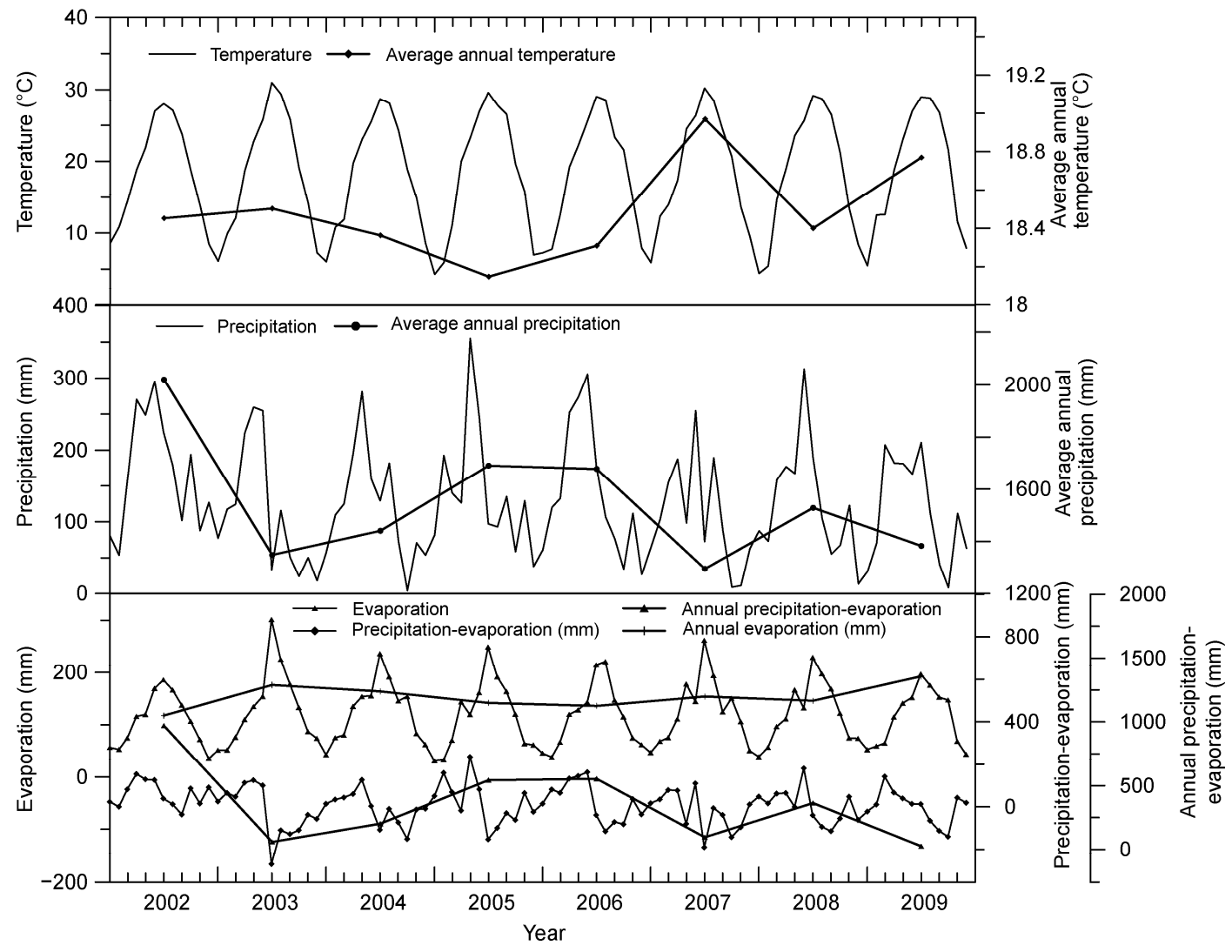

Figure 11 Monthly and average annual temperature, precipitation, and $E_{\mathrm{pan}}$ from 84 stations during 2002-2009 in the Poyang Lake basin, Jiangxi Province. The differences between precipitation and $E_{\mathrm{pan}}$ (precipitation minus $E_{\mathrm{pan}}$ ) from the same period are also shown. 
changes. This study also provides a method for validating the estimation of water volume changes of lakes for hydrological modeling.

This work was supported by the National Natural Science Foundation of China (41190081) and the China Postdoctoral Science Foundation (2011M500405). Provisions of Landsat data were provided by the USGS at http://glovis. usgs.gov/, ICESat through NSIDC, and meteorological data by China Meteorological Data sharing Service System are sincerely acknowledged. We also thank two anonymous reviewers for their valuable comments, which helped to improve this manuscript. We also thank Fan Jianyong at the Meteorological Bureau of Jiangxi Province for kindly providing meteorological data.

1 Lehner B, Döll P. Development and validation of a global database of lakes, reservoirs and wetlands. J Hydrol, 2004, 296: 1-22

2 Ma R, Yang G, Duan H, et al. China's lakes at present: Number, area and spatial distribution. Sci China Earth Sci, 2011, 54: 283-289

3 Guo Z, Miao Q, Li X. Variation characteristics of temperature over northern China in recent 50 years (in Chinese). Sci Geogr Sin, 2005, 25: $448-454$

4 Liu C, Du L, Chen X, et al. The change of effectively irrigated land area in China during the past 20 years (in Chinese). Resour Sci, 2006, 28: 8-12

5 Ma R, Duan H, Hu C, et al. A half-century of changes in China's lakes: Global warming or human influence? Geophys Res Lett, 2010, 37: L24106

6 Zhang G, Xie H, Kang S, et al. Monitoring lake level changes on the Tibetan Plateau using icesat altimetry data (2003-2009). Remote Sens Environ, 2011, 115: 1733-1742

7 Yao T, Thompson L, Yang W, et al. Different glacier status with atmospheric circulations in Tibetan Plateau and surroundings. Nat Clim Change, 2012, 2: 663-667

8 Lei Y, Yao T, Bird B W, et al. Coherent lake growth on the central Tibetan Plateau since the 1970s: Characterization and attribution. J Hydrol, 2013, 483: 61-67

9 Yang K, Ye B, Zhou D, et al. Response of hydrological cycle to recent climate changes in the Tibetan Plateau. Clim Change, 2011, 109: 517-534

10 Wang W C, Yao T D, Yang X X. Variations of glacial lakes and glaciers in the boshula mountain range, southeast Tibet, from the 1970s to 2009. Ann Glaciol, 2011, 52: 9-17

11 Li J L, Sheng Y W, Luo J C, et al. Remotely sensed mapping of inland lake area changes in the Tibetan Plateau (in Chinese). J Lake Sci, 2011, 23: 311-320

12 Guo H, Hu Q, Zhang Q, et al. Effects of the three gorges dam on yangtze river flow and river interaction with Poyang Lake, China: 2003-2008. J Hydrol, 2012, 416-417: 19-27

13 Guo H, Hu Q, Jiang T. Annual and seasonal streamflow responses to climate and land-cover changes in the Poyang Lake basin, China. J Hydrol, 2008, 355: 106-122

14 Dronova I, Gong P, Wang L. Object-based analysis and change detection of major wetland cover types and their classification uncertainty during the low water period at Poyang Lake, China. Remote Sens Environ, 2011, 115: 3220-3236

15 Gong P. Remote sensing of environmental change over China: A review. Chin Sci Bull, 2012, 57: 2793-2801

16 Medina C E, Gomez-Enri J, Alonso J J, et al. Water level fluctuations derived from envisat radar altimeter (ra-2) and in-situ measurements in a subtropical waterbody: Lake izabal (guatemala). Remote Sens Environ, 2008, 112: 3604-3617

17 Crétaux J F, Jelinski W, Calmant S, et al. Sols: A lake database to monitor in the near real time water level and storage variations from remote sensing data. Adv Space Res, 2011, 47: 1497-1507

18 Birkett C M. The contribution of topex/poseidon to the global monitoring of climatically sensitive lakes. J Geophys Res-Oceans,
1995, 100: 25179-25204

19 Phan V H, Lindenbergh R, Menenti M. Icesat derived elevation changes of Tibetan lakes between 2003 and 2009. Int J Appl Earth Obs Geoinf, 2012, 17: 12-22

20 Zhang G, Xie H, Duan S, et al. Water level variation of lake qinghai from satellite and in situ measurements under climate change. J Appl Remote Sens, 2011, 5: 053532-053515

21 Abdallah H, Bailly J S, Baghdadi N, et al. Improving the assessment of icesat water altimetry accuracy accounting for autocorrelation. ISPRS J Photogramm Remote Sens, 2011, 66: 833-844

22 Li J L, Chen X, Bao A M. Spatial-temporal characteristics of lake level changes in central asia during 2003-2009 (in Chinese). J Geogr Sci, 2011, 66: 1219-1229

23 Mischke S, Wünnemann B. The holocene salinity history of bosten lake (Xinjiang, China) inferred from ostracod species assemblages and shell chemistry: Possible palaeoclimatic implications. Quat Int, 2006, 154-155: 100-112

24 Zhang G, Xie H, Yao T, et al. Snow cover dynamics of four lake basins over Tibetan Plateau using time series modis data (20012010). Water Resour Res, 2012, 48: W10529

25 Zhang B, Wu Y H, Zhu L P, et al. Estimation and trend detection of water storage at Nam co lake, central Tibetan Plateau. J Hydrol, 2011, 405: $161-170$

26 Zhu L P, Xie M P, Wu Y H. Quantitative analysis of lake area variations and the influence factors from 1971 to 2004 in the Nam Co basin of the Tibetan Plateau. Chin Sci Bull, 2010, 55: 1294-1303

27 Yao T D, Li Z G, Yang W, et al. Glacial distribution and mass balance in the Yarlung Zangbo River and its influence on lakes. Chin Sci Bull, 2010, 55: 2072-2078

28 Zhai D, Xiao J, Zhou L, et al. Holocene east asian monsoon variation inferred from species assemblage and shell chemistry of the ostracodes from hulun lake, Inner Mongolia. Quat Res, 2011, 75: $512-522$

29 Liu Z M, Lu X G, Wu H T, et al. Study on lowest water level of Xingkai Lake for ecological safety (in Chinese). Water Resour Hydropower Eng, 2008, 39: 8-11

30 Li C, Ye B S, Yang Y S, et al. Study on the water level variation and dried-up situation in Hulun Lake in the 1900s (in Chinese). J Chin Hydrol, 2007, 27: 43-45

31 Feng L, Hu C, Chen X, et al. Assessment of inundation changes of poyang lake using modis observations between 2000 and 2010. Remote Sens Environ, 2012, 121: 80-92

$32 \mathrm{Hu} \mathrm{L}, \mathrm{Hu} \mathrm{W}$, Zhai S, et al. Effects on water quality following water transfer in Taihu Lake, China. Ecol Eng, 2010, 36: 471-481

33 Ma R, Duan H, Liu Q, et al. Approximate bottom contribution to remote sensing reflectance in Taihu Lake, China. J Great Lakes Res, 2011, 37: 18-25

34 Zwally H J, Schutz B, Abdalati W, et al. Icesat's laser measurements of polar ice, atmosphere, ocean, and land. J Geodyn, 2002, 34: 405-445

35 Zwally H J, Yi D H, Kwok R, et al. Icesat measurements of sea ice freeboard and estimates of sea ice thickness in the weddell sea. $\mathrm{J}$ Geophys Res-Oceans, 2008, 113: C02S15

36 Kwok R, Zwally H J, Yi D. Icesat observations of arctic sea ice: A first look. Geophys Res Lett, 2004, 31: L16401

37 Swenson S, Wahr J. Monitoring the water balance of Lake Victoria, east africa, from space. J Hydrol, 2009, 370: 163-176

38 Urban T J, Schutz B E, Neuenschwander A L. A survey of icesat coastal altimetry applications: Continental coast, open ocean island, and inland river. TerresAtmos Oceanic Sci, 2008, 19: 1-19

39 USGS. Phase 2 gap-fill algorithm: Slc-off gap-filled products gap-fill algorithm methodology. 2004, landsat.usgs.gov/documents/L7SLC GapFilledMethod.pdf

$40 \mathrm{Xu} \mathrm{H}$. Modification of normalised difference water index (ndwi) to enhance open water features in remotely sensed imagery. Int $\mathbf{J}$ Remote Sens, 2006, 27: 3025-3033

41 McFeeters S K. The use of the normalized difference water index 
(ndwi) in the delineation of open water features. Int J Remote Sens, 1996, 17: 1425-1432

42 Hui F, Xu B, Huang H, et al. Modelling spatial-temporal change of Poyang Lake using multitemporal landsat imagery. Int J Remote Sens, 2008, 29: 5767-5784

43 Ji L, Zhang L, Wylie B. Analysis of dynamic thresholds for the normalized difference water index. Photogramm Eng Remote Sensing, 2009, 75: 1307-1317

44 Taube C M. Instructions for winter lake mapping. Chapter 12. In: Schneider J C, ed. 2000. Manual of Fisheries Survey Methods ii: With Periodic Updates. Michigan Department of Natural Resources, Fisheries Special Report 25, Ann Arbor. 2000

45 Krause P, Biskop S, Helmschrot J, et al. Hydrological system analysis and modelling of the Nam co basin in Tibet. Adv Geosci, 2010, 27: 29-36

46 Meng K, Shi X, Wang E, et al. High-altitude salt lake elevation changes and glacial ablation in central Tibet, 2000-2010. Chin Sci Bull, 2012, 57: 525-534

47 Yao T, Pu J, Lu A, et al. Recent glacial retreat and its impact on hydrological processes on the Tibetan Plateau, China, and sorrounding regions. Arctic Antarctic Alpine Res, 2007, 39: 642-650

48 Bolch T, Yao T, Kang S, et al. A glacier inventory for the western Nyainqêntanglha Range and Nam Co basin, Tibet, and glacier changes 1976-2009. Cryosphere, 2010, 4: 419-433

49 Zhou S, Kang S, Gao T, et al. Response of zhadang glacier runoff in Nam Co basin, Tibet, to changes in air temperature and precipitation form. Chin Sci Bull, 2010, 55: 2103-2110

50 Bai M, Hao R, Shen J. Effects of climate change on eco-environment in hulun lake area in last 46 years (in Chinese). J Desert Res, 2008, 28: 101-107

51 Sun B. The dynamic change of water based on spatial information technology for Hulun Lake in Inner Mongolia (in Chinese). Dissertation for the Doctoral Degree. Hohhot: Inner Mongolia Agricultural University, 2010

52 Shankman D, Qiaoli Liang D. Landscape changes and increasing flood frequency in China's Poyang Lake region. Prof Geogr, 2003, 55: 434-445

53 Dai Z, Du J, Li J, et al. Runoff characteristics of the Changjiang River during 2006: Effect of extreme drought and the impoun of the Three Gorges dam. Geophys Res Lett, 2008, 35: L07406

54 Wang G, Li X, Miao Q. Variety characteristics of daily minimum air temperature in China in recent 50 years (in Chinese). Sci Geogr Sin, 2003, 23: 441-447

55 Mei W, Yang X. Trends of precipitation variations in the Mid-Lower Yangtze River Valley of China (in Chinese). J Najing Univ (Nat Sci), 2005, 41: 577-589

Open Access This article is distributed under the terms of the Creative Commons Attribution License, which permits use, distribution, and reproduction in any medium, provided the original author(s) and source are credited. 